\title{
Cell Maturation
}

National Cancer Institute

\section{Source}

National Cancer Institute. Cell Maturation. NCI Thesaurus. Code C28594.

Processes that create, promote, and maintain a differentiated cellular phenotype. $(\mathrm{NCl})$ 